машинобудівних підприємств/ B.I. Чобіток // Научно - практический журнал «Экономика и управление». - 2011. - №5 C. 168-174.

8. Фатхутдинов Р. А. Конкурентоспособность: Экономика, стратегия, управление / Р.А. Фатхутдинов - М.: ИНФРА - М , 2000. - 312 c.

DOI 10.18664/338.47:338.45.v\%vi\%i.133957
9. Tatar M. Complex of management models of the enterprise competitiveness for steel industry in the currency instable environment / M. Tatar, O. Sergienko, S. Kavun, L. Guryanova, // Economic Studies. - 2017. - Vol. 26. - Is. 5. - P.102-124.

УДК 658:331.108.2

\title{
ЗАБЕЗПЕЧЕННЯ ЕФЕКТИВНОСТІ МЕНЕДЖМЕНТУ ПРОМИСЛОВИХ ПІДПРИЕМСТВ НА ЗАСАДАХ УПРАВЛІННЯ ВИТРАТАМИ НА ПЕРСОНАЛ
}

\author{
Дикань В.Л., д.е.н., професор, \\ Засць Г.П., аспірант (УкрДУЗТ)
}

У статті визначено, щзо у процесі модернізації економіки України висуваються нові вимоги до ефективності менеджменту промислових підприємств, зумовлені підприємницькою активністю, зростанням динамічності бізнес-середовища, поглибленням розвитку ринкової економіки, глобалізацією економічних відносин, щуо потребує підвищеної уваги до персоналу промислових підприємств як основного чинника забезпечення конкурентоспроможності.

Розкрито основні підходи до формування ефективної системи управління персоналом підприємств, визначено функиії та проаналізовано концепції управління витратами на персонал. Також обрано подальші шляхи розвитку системи управляння витратами на персонал, систем менеджменту персоналу на вітчизняних промислових підприємствах для покращення роботи підприємства в иілому.

Ключові слова: ефективність, промислові підприсмства, управління витратами, менеджмент персоналу, управління витратами на персоналом, системи управління, розвиток персоналу.

\section{ОБЕСПЕЧЕНИЕ ЭФФЕКТИВНОСТИ МЕНЕДЖМЕНТА ПРОМЫШЛЕННЫХ ПРЕДПРИЯТИЙ НА ПРИНЦИПАХ УПРАВЛЕНИЯ РАСХОДОВ НА ПЕРСОНАЛ}

\author{
Дикань В.Л., д.э.н., профессор, \\ Заец А.П., аспирант (УкрГУЖТ)
}

В статье определено, что в процессе модернизации экономики Украинь выдвигаются новые требования к эффективности менеджмента промышленных предприятий, обусловленные предпринимательской активностью, ростом

(C) Дикань В.Л., Заєць Г.П.
Вісник економіки транспорту і промисловості № 62, 2018 297 
динамичности бизнес-среды, углублением развития рыночной экономики, глобализации экономических отношений, что требует повышенного внимания $\kappa$ персоналу промышленных предприятий как основного фактора обеспечения конкурентоспособности.

Раскрыты основныле подходы $к$ формированию эффективной системы управления персоналом предприятий, определень функции и проанализированы концепции управления затратами на персонал. Также избран дальнейшие пути развития системы управления затратами на персонал, систем менеджмента персонала на отечественных промышленных предприятиях для улучшения работы предприятия в целом.

Ключевые слова: эффективность, промышленные предприятия, управление затратами, менеджмент персонала, управление персоналом, системы управления, развитие персонала.

\title{
PROCURING EFFICIENCY OF MANAGEMENT OF INDUSTRIAL ENTERPRISES ON THE PRINCIPLES OF MANAGEMENT OF EXPENDITURES FOR PERSONNEL
}

\author{
Dykan V., doctor of economic sciences, professor, \\ Zaets A.P., postgraduate student (USURT)
}

In the article it is determined that in the process of modernization of the economy of Ukraine new requirements are put forward to the effectiveness of management of industrial enterprises due to entrepreneurial activity, growth of business environment dynamics, development of market economy, globalization of economic relations, which requires increased attention to the personnel of industrial enterprises as the main factor of ensuring competitiveness.

The main approaches to the formation of an effective system of personnel management of enterprises are revealed, the functions are defined and the concepts of managing personnel costs are analyzed. Also, further ways were chosen to develop the personnel cost management system, personnel management systems at domestic industrial enterprises to improve the work of the enterprise as a whole.

Key words: efficiency, industrial enterprises, cost management, personnel management, personnel management, management systems, personnel development.

\section{Постановка}

Підвищення ефективності функціонування промислових підприємств є важливою умовою забезпечення соціальноекономічного розвитку країни. Післякризове відновлення діяльності більшості промислових вітчизняних підприємств потребує пошуку нових шляхів їх розвитку, особливо сьогодні, коли в Україні поглиблюються процеси інтеграції та глобалізації. 3 подальшим розвитком економічних відносин на підприємствах набувають актуальності управлінські та економічні чинники, а саме питання стратегічного управління персоналом для оптимальної діяльності підприємства, побудови ефективної організаційної структури, забезпечення сталого розвитку підприємства в умовах нестабільності, конкурентоспроможності, раціонального використання наявних i потенційних можливостей, швидкої адаптації до змін у зовнішньому середовищі.

Досвід ведення господарювання промислових підприємств в розвинутих країнах свідчить про стабільну прибутковість підприємств за рахунок підвищення ефективності менеджменту. 
Враховуючи тенденції останніх років щодо збільшення частки витрат на персонал у загальних витратах підприємств, управління витратами на персонал перетворюється на один зі стратегічних аспектів ефективного функціонування підприємства. Таким чином, одним із актуальних напрямів забезпечення ефективності діяльності підприємства $\epsilon$ вдосконалення управління витратами на персонал.

Аналіз останніх досліджень i публікацій. Результати досліджень діяльності багатьох підприємств та накопичений ними досвід у процесі трансформаційних змін в економіці показує, що формування ефективної системи управління персоналом $\epsilon$ вирішальним фактором загальної ефективності підприємства. Особливо, коли характерною рисою управління будьяким підприємством стає зростання ролі людського фактору і розвиток нових форм i методів управління персоналом. Питанням управління персоналом, аналізу чинників, що впливають на вибір засобів i методів менеджменту персоналу присвячено роботи вітчизняних та зарубіжних вчених, серед яких: В. Дикань [3], В. Компанієць [9], Т. Сухорукова [11], I. Токмакова [14], Л. Калініченко [7], Й. Ситник [10], Л. Балабанова [1], В. Токарев [12] та ін. Управління витратами на персонал є однією з найбільш важливих сфер менеджменту промислових підприємства, що здатне багаторазово підвищувати його ефективність, саме тому це питання набуває актуальності для подальших досліджень.

Метою дослідження с: Метою статті $\epsilon$ розкриття теоретичних засад управління витратами на утримання i розвиток персоналу промислових підприємств.

Виклад основного матеріалу. Ефективність менеджменту полягає у ефективному управлінні персоналом, та $\epsilon$ одним 3 найважливіших напрямків в стратегії сучасного підприємства, оскільки в умовах розвитку високотехнологічного виробництва роль людських ресурсів зростає i рівень їх професійних знань повинен відповідати здібностям, рівню знань і кваліфікації пред'являються все більш високі вимоги. Перехід на ринкові відносини, ускладнення економічних зв'язків, науково-технічний прогрес, інтенсивно розвиває продуктивні сили, що призводять до глибоких змін методів праці, що в свою чергу вимагає більш чіткої й налагодженої структури управлінських органів, гнучких методів, різносторонності менеджерських рішень спрямованих на підвищення ефективності використання кадрового потенціалу.

В останні роки у світовій i вітчизняній економічній науці все більше уваги приділяється такому напрямку менеджменту як управління витратами. Оскільки частка витрат на персонал в загальному обсязі витрат має стійку тенденцію до зростання в усіх галузях економіки, особливо у високотехнологічних галузях промисловості i промислових підприємствах, вирішальне значення набуває управління витратами на персонал. У зв'язку 3 цим часто використовується поняття ефективності витрат на персонал. Тим часом, дослідниками по-різному визначається як саме поняття витрат на персонал, так i поняття їх ефективності. Відсутня і чітке обгрунтування необхідності оцінки ефективності витрат на персонал.

Питання управління витратами на персонал промислових підприємств $\epsilon$ важливим тому, що саме від даного процесу в теперішній момент часу залежить той обсяг грошових коштів, матеріальних, духовних благ, який отримує кожний робітник для своєї нормальної життедіяльності. Принципіальні зміни в процесі управління витратами на персонал обумовлені тим, що персонал не тільки унікальний ресурс, але і суттєва стаття витрат роботодавця. Систематизована інформація про ці 
витрати та їх аналіз необхідні роботодавцю для розробки ефективної в економічному та соціальному аспектах політики управління персоналом.

До середини XX століття в роботах економістів простежується вузький підхід до визначення витрат на персонал, який полягає в спробі звести витрати на персонал до витрат на оплату праці. Незважаючи на те, що до початку XX століття витрати на персонал вже безумовно не вичерпувалися оплатою праці, економісти намагалися абстрагуватися від інших видів витрат на працівників. Навіть в тому випадку, якщо в якості витрат на персонал виділялися, крім витрат на оплату праці, інші види витрат, вони носили другорядний характер.

До середини XX століття ситуація різко змінилася. Бурхливий розвиток світової економіки в післявоєнний період зумовило перегляд поглядів на фактори виробництва. В кінці 50 - початку 60-х років XX століття активно розвивається теорія «людського капіталу». Ї̈і зростаюча популярність i, як наслідок, масове поширення, змінюють i погляди економістів на поняття витрат на персонал. Однак, і сучасні вчені не прийшли до єдності у визначеннях поняття витрат на персонал. Пояснюється це різнобічними підходами до проблеми і розходженням цілей, досліджуваних тими чи іншими дослідниками в своїх роботах.

Найбільш змістовне визначення витрат на персонал - це витрати які представляють собою ту частину новоствореної в процесі суспільного відтворення вартості, яка утворює фонд життєвих засобів, потрібних для відтворення робочої сили в конкретних соціально-економічних та історичних умовах [14]. Причому витрати на персонал розглядаються як зведене поняття, яке включає витрати бюджетів різних рівнів, витрати роботодавців, а також кошти громадян «на формування i розвиток здібностей до праці». Можна обгрунтовано говорити про утворення якоїсь частки фонду, так як поняття «фонд коштів» має на увазі певну концентрацію цих засобів, спільність їх складу і джерел ix формування. Проте, призначення витрат на персонал не може бути обмежена відтворенням робочої сили.

Дане визначення, на наш погляд, орієнтоване на розгляд витрат на персонал 3 точки зору підприємств промисловості, тобто носить мікроекономічний характер; що в свою чергу при формуванні визначення дозволяе звертатися до категорії суспільного відтворення. Саме тому має місце подібне розгляд питання про джерело покриття витрат на персонал.

Витрати на персонал як інтегральний показник, який включає в себе витрати, пов'язані із залученням, винагородою, стимулюванням, використанням, розвитком, соціальним забезпеченням, організацією праці та поліпшенням ii умов праці, звільненням персоналу. Це визначення фактично являє витрати на персонал як перелік витрат на певні напрямки роботи 3 персоналом. Згідно з наказом Міністерства статистики України від 29 травня 1997 р. №131 [16] фактичні витрати роботодавців на персонал (вартість робочої сили) визначаються за такими складовими групами:

1. Пряма оплата.

2. Оплата за невідпрацьований час.

3. Премії та нерегулярні виплати.

4. Заробітна плата в натуральній формі, пільги, послуги, допомоги в натуральній і грошовій формах. працівників.

5. Витрати на оплату житла

6. Витрати на соціальне забезпечення працівників.

7. Витрати на професійне навчання.

8. Витрати на утримання громадських служб.

9. Витрати на робочу силу, які не віднесені до інших груп.

10. Податки, що відносяться до витрат на робочу силу. 
На наш погляд, необхідно уникати ототожнення поняття витрат на персонал 3 конкретними напрямками роботи 3 персоналом - це дозволить зробити визначення менш залежним від появи нових i видозміни існуючих напрямків роботи 3 персоналом. Крім того, ми вважаємо, що послідовне перерахування напрямків (від залучення до звільнення) передбачає певний життєвий цикл даної категорії, тобто його взаємозв'язок 3 конкретним співробітником. Наприклад, на підприємствах Японії поряд 3 практикою «довічного найму» існує практика професійної наступності, коли підприємство здійснює витрати не тільки на співробітників, але і на їх дітей, бере участь в їх навчанні і розвитку, з тим, щоб 3 часом вони також надійшли на роботу на це підприємство.

Сутність витрат на персонал проявляється в їх функціях. Доцільно виділити, принаймні, чотири основні функції [15]:

1. Розподільча. Виявляється в розподілі фонду коштів, утвореного для функціонування системи управління персоналом по підсистемах відповідно до ix призначення, 3 чого можна зробити висновок про цільовий характер витрат на персонал.

2. Контрольна. Виявляється в контролі за формуванням фонду та цільовим характером використання коштів, які витрачаються 3 фонду, i ïx розподілом за відповідними підсистемами.

3. Стимулююча. Виявляється в залежності результатів діяльності системи управління персоналом від обсягу коштів, що надходять до фонду, і термінів його формування. Зміна обсягу коштів, що спрямовуються в ту чи іншу підсистему, сприяє підвищенню (зниження) можливостей діяльності даної підсистеми.

4. Інноваційна. Саме людина, персонал в епоху науково-технічного прогресу $є$ головним носієм і творцем технологічних змін, на яких в значній мірі i базується науково-технічний прогрес.
Інноваційна функція витрат на персонал проявляється в тому, що кошти, що утворюють фонд, $є$ основним джерелом нарощування інноваційного потенціалу промислових підприємств, реалізації іiі конкурентних переваг. Отже, чим більше підприємство орієнтовано на інновації, сучасні технології, тим більшою мірою його благополуччя залежить від реалізації даної функції.

Стосовно витрат на персонал слід відзначити наступне. Той факт, що розгляд нами ролі персоналу у чому спирається на теорію «людського капіталу », яка перестає розглядати витрати на персонал, як споживчі витрати, i встановлює їх продуктивний характер, дозволяє вважати витрати на персонал здатними приносити дохід в різних формах. Не викликає сумніву і те, що в процесі здійснення витрат відбувається перетворення капіталу, що бере участь в виробничому процесі, в інші форми. Слід відзначити, що дане перетворення не тільки має місце, але i $\epsilon$ необхідним умовою діяльності будь-якого підприєства.

Цілеспрямований характер витрат на персонал ми встановили в процесі визначення функцій. Управління витратами на персонал в системі управління персоналом - це сукупність послідовних та безперервних управлінських дій, безпосередньо пов'язаних з витратами, що виникають у процесі функціонування підсистем управління персоналом, метою яких $\epsilon$ забезпечення ефективності діяльності підприємства [2]. Система управління витратами на персонал включає в себе:

1) суб'єкт, який здійснює операції над об'єктом управління (керуюча підсистема), а саме структурні підрозділи та конкретні посадові особи, які беруть участь в управлінні витратами на персонал;

2) об’єкт, на який спрямована дія системи (керована підсистема) власне витрати на персонал; 
3) мета, відповідно до якої здійснюється вплив суб'єкта на об'єкт управління;

4) процес управління витратами на персонал, який представляє собою хід реалізації системою управлінських функцій, тобто певну послідовність виконання операцій над об'єктом [5].

Мало розглянутими для українських підприємств $є$ показники витрат на персонал. Їх аналіз дає можливість оцінити раціональність структури цих витрат, рівень оплати праці та іii диференціації, ступінь соціальної захищеності працівників з боку держави і з боку підприємства, рівень соціального розвитку підприємства, участь персоналу у прибутках, структуру доходів працівників. Серед них: витрати на заробітну плату, витрати на соціальні виплати, витрати на додаткові соціальні виплати та пільги, витрати на утримання соціальної інфраструктури їх частка в загальній сумі, середній розмір дивідендів, витрати на навчання та розвиток персоналу та інші.

Нами вже відзначався продуктивний характер витрат на персонал, їх здатність приносити дохід i ефект в цілому. В зв'язку 3 цим представляється необхідним розглянути поняття ефективності витрат на персонал. Перш за все, будемо виходити з того, що витрати на персонал нерозривно пов'язані 3 системою управління персоналом промислових підприємств, яку, в свою чергу, необхідно розглядати як найважливішу частину системи внутрішньо підприємницького менеджменту. Таким чином, ефективність витрат на персонал пов'язана ефективністю підприємства в цілому. Функціонування

системи менеджменту на засадах управління витратами пропонується розглядати в вигляді ланцюжка «витрати - результат цілі (функції)». Поняття ефективності автоматично прив'язується до завершеності даної ланцюжка. Тобто, система менеджменту може бути визнана ефективною тільки в тому випадку, якщо витрати на персонал не просто успішно перетворюються в результати (тобто підвищення продуктивності праці, покрашення виробітку), але і отримані результати відповідають при цьому цілям (функціям) економічних систем (промислових підприємств). Дане уявлення здається нам найбільш справедливим i застосування його для промислових підприємств, де для кожного підприємства $є$ визначальним таке поняття, як стратегія розвитку та ефективність діяльності. Орієнтування стратегії промислових підприємств на конкретний результат для системи ефективного менеджменту є визначальним фактором в питанні ефективності діяльності підприємства та максимально раціонального використання трудових ресурсів.

Процес перетворення ресурсів має на увазі отримання результату i досягнення цілей. Звідси необхідність оцінки ефективності витрат на персонал. В тому випадку, якщо ресурси будуть витрачатися, а цілі підприємства при цьому досягатися не будуть, функціонування системи буде порушено, що приведе до іii неминучого розпаду. Саме тому оцінка ефективності витрат на персонал повинна проводитися на постійної основі. Важливість оцінки ефективності витрат на персонал слід також 3 їх значною частки в загальному обсязі витрат. Наприклад, в промисловій галузі $65-70 \%$ витрат може доводитися на частку витрат на персонал.

Так як під ефективністю розуміється, перш за все, економічна ефективність, то основні результати також будуть виражатися економічними показниками такими, як рівень доходів, фінансовий результат i т.д. Варто відзначити, що збільшення результату може досягатися як 3 допомогою екстенсивних методів (наприклад, збільшення числа співробітників, обсягу 
виконуваних робіт i, відповідно, обсягу витрат), так і з допомогою інтенсивних методів, останні являють значно більший інтерес для дослідження.

\section{Результатом}

інтенсивних методів може бути, наприклад, збільшення продуктивності праці. Саме такий підхід простежується в роботах багатьох дослідників. Додамо, що поліпшення результату досягається не просто за рахунок приросту продуктивності праці, але i за рахунок збільшення якості i раціональності прийнятих управлінських рішень, більш чіткої організаційної системи управління персоналом і промисловим підприємством в цілому, точних прогнозів що до використання персоналу в промислових підрозділах, зниження ризиків, недопущення порушень. До вищесказаного можна додати, що джерело приросту результатів слід шукати не тільки в прирості відповідних показників, але i в недопущення, запобігання втрат i збитків як прямих, так i непрямих на персонал.

Високий рівень розвитку сучасних технологій веде до витіснення 3 процесу виробництва низько кваліфікованих працівників та носіїв застарілих професій, що може бути використаний як шлях для скорочення витрат на персонал, сприятиме найму адаптованого до вимог сучасних технологій персоналу, який досить гнучко реагує на професійні зміни. 3 одного боку, менеджери організацій повинні суттєво змінювати вимоги до працівника, професійно-кваліфікаційної і структурної зайнятості. 3 другого - зростає роль i значення працівників у забезпеченні ефективності виробництва.

У той час як система управління витратами на персонал являє собою взаємодію керуючої та керованої підсистем, що забезпечує оптимізацію витрат на персонал, на основі узгодження методичного, нормативно-правового, організаційного аспектів щодо вибору напрямків витрат на персонал, визначення ïx величини і джерел відшкодування.

В процесі управління витратами на персонал надзвичайно важливим завданням $є$ визначення ефективності. Вихідним моментом для планування всіх інших показників з праці на промислових підприємствах в ринкових умовах господарювання $\epsilon$ визначення допустимої величини витрат на персонал в виробництві одиниці вартості продукції. Тому найважливішим трудовим показником стає частка витрат па персонал у вартості продукції. Особливого значення планування витрат на персонал набуває ще й тому, що 3 розвитком суспільства наймана робоча сила буде неухильно дорожчати та потребувати спеціалістів більш широкого спектру робіт а не вузько профільних спеціалістів. [3].

У зв'язку 3 цим на кожному підприємстві потрібно створювати чітку i прозору систему показників 3 праці та витрат на персонал, що дає змогу здійснювати аналіз та планування діяльності, а також оцінювати свою конкурентоспроможність на науковій основі.

Загальноекономічні показники дають можливість оцінити масштаби виробництва, фінансовий стан та рівень соціального розвитку підприємства. Це такі показники як: обсяг виробництва по підприємству, вартість основних фондів, питома вага основних фондів невиробничого призначення, прибуток, питома вага фонду споживання в прибутку.

Кадрові показники свідчать про чисельність трудового колективу, якість людського потенціалу, раціональність структури персоналу тощо. До них відносять: чисельність персоналу, частка професіоналів та фахівців, частка керівників, частка робітників, частка технічних службовців, середній кваліфікаційний розряд робітників, рівень плинності кадрів, середній вік працівників тощо. 
Співвідношення показників, що характеризують результат діяльності промислових підприємств (обсяг виробництва, величина прибутку), i показників витрат дає найважливіші для економічного аналізу дані - показники ефективності. Ефективність використання трудових ресурсів визначається передусім продуктивністю праці, рентабельністю витрат на персонал і часткою витрат на персонал у вартості продукції.

Слід звернути особливу увагу на показники, що характеризують умови праці: рівень травматизму, частка працюючих у шкідливих умовах, рівень захворюваності, витрати на пільги та компенсації за шкідливі умови, тощо.

Висновки: Отже побудова ефективної системи управління персоналом на сучасних підприємствах $\epsilon$ запорукою ефективності управління ним. Узагальнюючи викладений вище матеріал щодо змін організаційних процесів та розвитку теоретичного підгрунтя функціонування сучасних промислових підприємств, основну увагу підкреслено на таких ключових аспектах розвитку управління персоналом в системі менеджменту:

- криза парадигми традиційного менеджменту, в першу чергу, відображається в практичній діяльності сучасних організацій, що набувають рис надскладної системи та змушені реагувати на постійно зростаючу кількість факторів як внутрішнього, так i зовнішнього середовища. За таких умов а ні концепція, a ні практичний інструментарій традиційного менеджменту не надають дієвих засобів для стійкого функціонування організації та іiі розвитку; - здобутки різноманітних шкіл традиційного менеджменту, в тому числі стратегічного менеджменту, стають необхідними, проте не визначальними факторами успіху сучасних організацій;

- сучасні наукові розробки щодо теоретичних засад діяльності організацій у висококонкурентному пропонують дуже широкий перелік бізнесконцепцій, які не складають єдиної системи та, переважно, акцентують увагу на окремих явищах, процесах, функціональних сферах діяльності організації;

- сучасна економічна наука не пропонує єдиного підходу до вивчення та пояснення організаційних процесів та управління витратами на персонал, що засвідчуе доволі значна кількість різноманітних позицій щодо подальшого розгляду цих питань.

Врахування всіх аспектів ефективного менеджменту при управлінні витратами на персонал дозволить підвищити лояльність персоналу, утримати найкращих працівників, розвинути стратегічні компетенції, знизити структуру ризиків, вивільнити грошові кошти на розвиток персоналу тощо. Саме тому, необхідно розробляти актуальні напрямки забезпечення ефективності діяльності промислових підприємств, та вдосконалювати управління витратами персоналу.

\section{СПИСОК ВИКОРИСТАНОЇ ЛІТЕРАТУРИ}

1. Балабанова Л. В. Стратегічний менеджмент управління комерційною діяльністю підприємств : монографія / Л. В. Балабанова, А. С. Панчук .- Донецький нац. ун-т економіки i торгівлі ім. М. І. Туган- Барановського. Донецьк : ДонНУЕТ, 2011. - 181 с.

2. Дикань В. Л. Сутнісні аспекти конкурентоспроможності національної економіки / В. Л. Дикань, О. Г. Кірдіна // Вісник економіки транспорту та промисловості. - 2009. - № 28 . - С. 13 20.

3. Дикань

В.Л. Реанимирование экономики Украины / В.Л. Дикань// Вісник економіки транспорту i промисловості: збірник наукових праць. - Харків: УкрДАЗТ. 2014. - №. 45. - C. 11 - 17. 
4. Дикань В.Л. Стратегічне управління: навчальний посібник / В.Л. Дикань, В.О. Зубенко, I.В. Токмакова, О.В. Маковоз, О.В. Шраменко. - К.: «Центр учбової літератури», 2013. - 272 с.

5. Дикань О.В. Стратегічний менеджмент та його використання в практиці формування і досягнення цілей розвитку залізничного транспорту / O.B. Дикань, О. В. Смаль // Вісник економіки транспорту та промисловості. - 2017. - № 59 . - C. 230-235.

6. Каличева Н.С. Організація управління на підприємствах залізничного транспорту в сучасних умовах / H.C. Каличева // Вісник економіки транспорту і промисловості. - 2014. - №. 45. - С. 167 170.

\section{7. Калініченко}

Л.

Л. Соціально-економічна модернізація залізничного транспорту України / Дикань В.Л., Л. Л. Калініченко // Розвиток методів управління та господарювання на транспорті - 2012. - Т. 1, Випуск. - С.98112.

8. Канафоцька Г. Нова парадигма менеджменту XXI століття / Г. Канафоцька [Електронний ресурс]. Режим доступу : http://www. vox. com. ua/data/publ/2007.

$\begin{array}{ccc}9 . & \text { Компанієць } & \text { В. } \\ \text { Управління } & \text { розвитком } \\ \text { економічних } & \text { систем } & \text { соціально- } \\ \text { духовно- }\end{array}$ економічних систем у духовноЧастина 2. Якість управління соціальноекономічними системами: духовноморальні та культурні пріоритети (на прикладі залізничного транспорту): монографія / В. В. Компанієць. - Харків: УкрДАЗТ, 2012. - 296 с.

10. Ситник Й.М. Засади формування парадигми менеджменту світогляду й особистісно-власницького зростання / Й.М. Ситник // Вісник Національного університету «Львівська політехніка».

Менеджмент

та

підприємництво в Україні: етапи

становлення і проблеми розвитку. - 2013. - № 778. - С. 196-205 [Електронний pecypc]. - Режим доступу : http://vlp.com.ua/node/12193.

11. Сухорукова Т.Г. Управління розвитком персоналу підприємства // Вісник економіки і промисловості. - 2017 - № 59. - С. 256 - 264.

12. Токарев В.Г. Гипотеза о новой парадигме управления / В. Г.Токарев // Проблемы теории и практики. - 2001. - № 3 [Електронний ресурс]. Режим доступу

http://vasilievaa.narod.ru/8_3_01.htm.

13. Токмакова І.В. Розвиток технологій управління знаннями на підприємствах / I.B. Токмакова, I.M. Войтов, Я.В. Діденко // Вісник економіки транспорту та промисловості. - 2017. - № 60. - C. 258-264.

14. Токмакова I.В. Стратегічне управління персоналом на підприємствах залізничного транспорту / I.В. токмакова, А.В. Кузуб // // Вісник економіки транспорту та промисловості. - 2016. - № 53. - C. 110-114.

15. Толстова А.В. Модель організаційної структури управління конгломератом «Інноваційнотехнологічний центр розвитку транспортної системи України» / А.В. Толстова // Вісник Харківського національного аграрного університету: збірник наукових праць. - Харків: ХНАУ, 2010. - Вип. 10, Серія: «Економічні науки». - С. 270-279.

16. Наказ Міністерства статистики України від 29 травня 1997 р. №131 [Електронний ресурс]. - 1997. Режим доступу до ресурсу: http://zakon2.rada.gov.ua/laws/show/z0258-

97. 